\title{
Disparity in Microbiological Pattern of CAUTI in Precisely Tribal Patients in Relation to Impacting Factors from the Known Pattern in the Medical Intensive Care Unit in a Tribal Tertiary Care Centre
}

\section{Monalisa Subudhi $^{1}$ (D), PAT Jagatheeswary ${ }^{2}$ (D), Sudhanshu Kumar Das $^{3 *}$ (D), Khetrabasi Subudhi ${ }^{4}$ iD and Rashmiranjan Rout ${ }^{5}$ iD}

\footnotetext{
${ }^{1}$ Department of Microbiology, Gayatri Vidya Parishad Institute of Health Care \& Medical Technology, Visakhapatnam, Andhra Pradesh, India.

${ }^{2}$ Department of Microbiology, Saveetha Institute of Medical \& Technical science, Chennai, Tamil Nadu, India. ${ }^{3}$ Department of Pediatrics, Gayatri Vidya Parishad Institute of Health Care \& Medical Technology, Visakhapatnam, Andhra Pradesh, India. ${ }^{4}$ Department of Obstetric \& Gynaecology, Gayatri Vidya Parishad Institute of Health Care \& Medical Technology, Visakhapatnam, Andhra Pradesh, India.

${ }^{5}$ Department of Microbiology, SLN Medical College, Koraput, Odisha, India.
}

*Correspondence: swayam.dr007@gmail.com

(Received: November 07, 2020; accepted: May 22, 2021)

Citation: Subudhi M, Jagatheeswary PAT, Das SK, Subudhi K, Rout R. Disparity in Microbiological Pattern of CAUTI in Precisely Tribal Patients in Relation to Impacting Factors from the Known Pattern in the Medical Intensive Care Unit in a Tribal Tertiary Care Centre. J Pure Appl Microbiol. 2021;15(2):949-957. doi: 10.22207/JPAM.15.2.53

(C) The Author(s) 2021. Open Access. This article is distributed under the terms of the Creative Commons Attribution 4.0 International License which permits unrestricted use, sharing, distribution, and reproduction in any medium, provided you give appropriate credit to the original author(s) and the source, provide a link to the Creative Commons license, and indicate if changes were made. 


\begin{abstract}
The important risk factor for the development of CAUTI, especially in the intensive care units, is the presence, method and length of Duration of urinary catheterization. The other potential significant risk factors are gender, age, uncontrolled diabetes and long hospital stay. There have been no studies on Tribal patients describing the factors (Demographic as well as Risk factors) which influence the deviation in microbiological pattern of CAUTI in of the MICU, from the patients of other area studied till now. This prospective study was conducted over Tribal patients aged $\geq 18$ years who developed features of symptomatic urinary tract infection following an indwelling urinary Foley's catheter more than 48 hours, in the Medical Intensive Care Unit. Geographical and Clinical data were collected. The CAUTI rate in 33 Tribal patients was 19.2 per 1000 device days with an incidence of $17.3 \%$ in the MICU. The microbiological trend was Staphylococcus aureus 12 (26.0\%), E. coli 11 (23.9\%), Candida albicans 9 (19.5\%), Klebsiella pneumoniae 5 (10.8\%), CONS 3 (6.5\%), Streptococcus pneumoniae 3(6.0\%), Pseudomonas aeruginosa 2 (4.3\%) and Acinetobacter baumannii 1(2.1\%). Staphylococcus aureus was the common cause of CAUTI in low and medium socioeconomic tribal patients of more than 20 to 40 years of age, as compared to $E$. coli in Nontribal Patients. E.coli was found in the dominated female patients and in age upto 20 years and more than 40 to 60 years old patients and Klebsiella pneumoniae in above 60 years of age. High status group with Acinetobacter baumannii. Candida albicans was associated with use of urinary catheter less than 7 days. Length of ICU stay more than 14 days was associated with E. coli and Staphylococcus aureus in equally proportionately. CONS 2(50\%) was found in type-2 Diabetes mellitus and Staphylococcus aureus 7 (53.8 \%) with Sickle cell anemia in Tribal patients. Our analysis precisely of these Tribal patients, brings several important and unique findings, which will not only aid in the development of some new or update guidelines but also encourage the researcher to do more study, for the prevention of CAUTI in the MICU of Tribal tertiary care centre.

Keywords: Catheter associated urinary tract infection (CAUTI), Centers for Disease Control \& prevention (CDC), National Healthcare Safety Network (NHSN), Sickle cell anemia (SCA), Diabetes mellitus (DM), Coagulase negative Staphylococcus (CONS), Device utilization rate (DUR)
\end{abstract}

\section{INTRODUCTION}

Urinary tract infection (UTI) is an infection in any part of the urinary system, including kidney, ureter, bladder, or urethra. Urinary tract infection is the presence of the microorganism in the urine ${ }^{1}$. It is a common health care associated infection (HAI) accounting for $30-50 \%$ of $\mathrm{HAl}$ and comprising $8 \%$ to $21 \%$ of all HAl in intensive care units (ICUs) ${ }^{2,3}$. The incidence of UTls among hospitalized patients with indwelling catheters is approximately $15 \%^{4}$. The Centers for Disease Control and Prevention (CDC) simplified the definition of CA-UTI, the indwelling catheter must be in place for $>2$ calendar days on the date of event, with day of device placement being Day 1 , with at least one of the following clinical features like fever $\left(>38^{\circ} \mathrm{C}\right)$, frequency, urgency, suprapubic tenderness, dysuria and a positive urine culture of a bacterium $\geq 10^{5}$ colony forming unit (CFU) $/ \mathrm{ml}^{5}$.

Because of frequent use of urinary catheter in the ICU than hospital ward,to calculate intake and output in sick patient, the risk of CAUTI is significantly higher in the ICU. Not only use of urinary catheter but also duration of use of catheter is a major risk factor for development of CAUTI in the ICU ${ }^{6-8}$. The other risk factors associated with the cause of CAUTI are female gender, poor nutrition, severity of illness, and

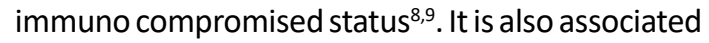
with many complications leading to increase morbidities and mortalities in the ICUs. Even if it is the most preventable health care associated infection (HAI), the management of CAUTI is still a challenge. In CAUTI the incidence of infection is Escherichia coli in $21.4 \%$, Candida spp in $21.0 \%$, Enterococcus spp in $14.9 \%$ Pseudomonas in $10.0 \%$, Klebsiella in $7.7 \%$ and remaining part with other organisms $s^{6,9}$.

We know, what are the potential risk factors and pattern of microbiological profile of CAUTI, in the ICU of Rural and Urban area tertiary care centers. But we do not have any knowledge or any recent studies describing the factors and microbiological pattern of CAUTI in specially tribal people. Because of unawareness, lack of health consciousness and living style, make them 
more prone for infection leading to more ICU admission, morbidity and mortality. Here we tried to explore the factors (demographic as well as risk factors) responsible for more incidence of CAUTI and also their influence on the microbiological profile of CAUTI, which vary according to all this. So that, preventive strategies should be planned such as antibiotic policy, protocol for using device, health awareness in the ICU to give quality health care and reduce morbidity and mortality in tribal people in the ICU of any hospital in Tribal area.

\section{The aim of our study was to find out the}

1. Incidence of Catheter associated urinary tract infections (CAUTI) in precisely, ethnic group of Tribal People in the Medical Intensive Care Unit.

2. The Influencing factors (Demographic as well as risk factors) in people of Tribal, in compared to other area, that influence the variation in microbiological pattern of CAUTI in the Medical Intensive Care Unit (MICU)

3. Any discrepancy between the microbiological pattern of CAUTI in Tribal \& Nontribal people of same Medical Intensive Care Unit (MICU) of a tribal tertiary care centre.

\section{MATERIAL AND METHODS Study Design}

This prospective study was conducted in the 20 bedded Medical Intensive Care Unit of SLN Medical College and Hospital, Koraput, from April 2019 to March 2020 with the approval of ethical committee of the institution.

\section{Inclusion criteria}

1. MICU patients aged $\geq 18$ years old.

2. All MICU patients with transurethral indwelling catheter for $>48$ hours.

3. Patients, who are willing to give, an admission urine sample following catheterization for culture and sensitivity to rule out preexisting UTI.

4. Patients having symptoms with microbiological confirmation of pyuria.

5. Patients with risk factors as Diabetes mellitus and Sickle cell anemia.

6. Who are willing and signed the consent form to take part in the study.

\section{Exclusion criteria}

1. Patients with pre existing UTI,

2. Presence of signs and symptoms of CAUTI within 2 calendar days of catheterization.

3. Patients who used antibiotics more than 2 weeks before the time of the study.

4. Risk factors other than DM and SCA.

\section{Study population}

The study population was all adult patients, aged $\geq 18$ years, admitted to MICU with different complaints with an indwelling urinary Foley's catheter. catheter more than 48 hours during their admission, in a Tribal tertiary care centre. between the study period from April 2019 to March 2020, developed features of symptomatic urinary tract infection following catheterization were included in the study.

\section{Sample Collection}

The urine sample was collected aseptically from the sampling port of indwelling urinary catheter with sterile syringe and needle and distal $5 \mathrm{~cm}$ of the aseptically removed urinary catheter was cut and sent to microbiology Department for routine microscopic examination and Culture sensitivity test.Infection surveillance and consent form with necessary details were filled up simultaneously. Urine culture showing, more than $10^{5}$ colony-forming units per $\mathrm{ml}$, with one or two micro-organisms isolated was considered as a confirmation of UTI. CAUTI was considered when urine showed Pyuria (more than 10 leucocyte $/ \mathrm{ml}$ of urine) or more than 3 WBC were seen per HPF in centrifuged urine and organism seen on gram stain. Standard culture methods MacConkey's agar, and cysteine lactose electrolyte deficient (CLED) agar, were used, to identify the microorganism,. Susceptibility of antimicrobials was done by the disk diffusion method on isolates.

\section{Data collection}

The demographic and clinical data of patients were collected as follows: age, gender, Socioeconomic status, area, admission date, indication and duration of catheterization, risk factors,co morbidities like presence of Diabetes mellitus, Sickle cell anemia, length of ICU stay, previous antibiotic use, and severity of illness. Detailed investigations of the patients were taken. Culture and sensitivity and antimicrobial susceptibility and resistance pattern of isolates were collected.

\section{Statistical analysis}

Microsoft Excel was used for data entry and analyzed with SPSS software version 20.0. For 
Table 1. Incidence of CAUTI

\begin{tabular}{lc}
\hline $\begin{array}{l}\text { Total number of Patients in the MICU } \\
\text { studied }\end{array}$ & 190 \\
$\begin{array}{l}\text { Total Number of Patient developed } \\
\text { CAUTI }\end{array}$ & 46 \\
$\begin{array}{l}\text { Incidence of CAUTI in Total } \\
\text { Total Number of Tribal Patient }\end{array}$ & $24.2 \%$ \\
$\begin{array}{l}\text { developed CAUTI } \\
\text { Incidence of CAUTI in Tribal Patients }\end{array}$ & 33 \\
Device-associated infection rate in & $17.3 \%$ \\
Tribal Patients & \\
\end{tabular}

quantitative variable, median and for qualitative variable,frequency (percentage) were used to present the results.

\section{RESULTS}

The study was conducted in a 20 bedded medicine intensive care unit, over a period of one year from April 2019 to March 2020 in a Tribal tertiary care centre. Total 190 patients were exposed to indwelling urinary catheter device for a total duration of 1712 device days and treated for an aggregated duration of 2772 days with different complaint in the MICU. The Device utilization rate (DUR) was 0.61 . Out of 190 catheterized patients, $46(24.2 \%)$ were diagnosed microbiologically as
CAUTI with an incidence of $24.2 \%$ and Deviceassociated infection rate in total was $26.8 / 1000$ days. Where as, the CAUTI rate in 33 Tribal patients was 19.2 per 1000 device days with an incidence of $17.3 \%$.(Table 1$)$.

The type of patients developed CAUTI in our MICU,were Tribals 33 (71.7\%) and Nontribals 13 (28.3\%). Among these 33 Tribal patients, females were $20(60.6 \%)$ as compared to males 13 $(39.4 \%)$. Where as in factor, age of tribal patient, $6(18.1 \%)$ were under upto 20 years, $7(21.2 \%)$ in $>20-40$ years, 15 (45.4\%) in >40-60 years and 5 (15.1\%) cases in above 60 years old respectively. Depending upon the Socioeconomic status, most of the tribal patients 21 (63.6\%) were under low socioeconomic status group than 11 (33.3\%) in medium and $1(3.0 \%)$ in high status group. Considering the risk factors associated with Tribal patients in the study, Diabetes Mellitus in 4 (12.1\%) case, Sickle cell anemia in $13(39.3 \%)$ cases and others in $16(48.4 \%)$ were without any risk factors in the study. Length of ICU stay was an another risk factor to develop CAUTI in our study, according to which 22(66.6\%) patients stayed for 7-14 days,8 (24.4\%) for less than 7 days and $3(9.0 \%)$ stayed for more than 14 days. Single organism responsible for CAUTI in tribal people of our study were Bacteria

Table 2. Percentage of CAUTI associated with different Influencing factors in Tribal Patients

\begin{tabular}{|c|c|c|c|}
\hline \multicolumn{2}{|c|}{$\begin{array}{l}\text { Influencing factors in } \\
\text { Tribal Patients }\end{array}$} & \multirow{2}{*}{$\begin{array}{l}\text { No of Patient developed } \\
\text { CAUTI. (Total-33) } \\
20\end{array}$} & \multirow{2}{*}{$\begin{array}{l}\begin{array}{l}\text { Percentage(\%) } \\
\text { of CAUTI }\end{array} \\
60.6 \%\end{array}$} \\
\hline Sex & Female & & \\
\hline & Male & 13 & $39.4 \%$ \\
\hline \multirow[t]{4}{*}{ Age } & Upto 20 years & 6 & $18.1 \%$ \\
\hline & $>20-40$ years & 15 & $45.4 \%$ \\
\hline & $>40-60$ years & 7 & $21.2 \%$ \\
\hline & $>60$ years & 5 & $15.1 \%$ \\
\hline SocioEconomic & Low & 21 & $63.6 \%$ \\
\hline \multirow{2}{*}{ status } & Medium & 11 & $33.3 \%$ \\
\hline & High & 1 & $03.0 \%$ \\
\hline \multirow[t]{3}{*}{ Risk Factors } & withType2DM & 4 & $12.1 \%$ \\
\hline & With SCA & 13 & $39.3 \%$ \\
\hline & Without factor & 16 & $48.4 \%$ \\
\hline Duration of & $<7$ days & 8 & $24.4 \%$ \\
\hline \multirow[t]{2}{*}{ Catheterisation } & $7-14$ days & 22 & $66.6 \%$ \\
\hline & $>14$ days & 3 & $9.0 \%$ \\
\hline \multirow[t]{2}{*}{ Length of ICU stay } & $<14$ days & 14 & $42.4 \%$ \\
\hline & $>14$ days & 19 & $57.5 \%$ \\
\hline \multirow[t]{2}{*}{ (Single organism) } & Bacteria & 28 & $84.8 \%$ \\
\hline & Fungal & 5 & $15.1 \%$ \\
\hline
\end{tabular}


Table 3. Spectrum of Pathogens according to Type of Patients in the MICU

\begin{tabular}{|c|c|c|c|c|c|}
\hline \multirow{2}{*}{$\begin{array}{l}\text { Pathogens in CAUTI } \\
\text { Type of Pathogens }\end{array}$} & \multirow[b]{2}{*}{ Total $(n=46)$} & \multirow{2}{*}{$\begin{array}{l}\text { TribalPatient } \\
(33=71.7 \%) \\
\text { Bacteria(28) / } \\
\text { Fungal(5 }\end{array}$} & \multicolumn{3}{|c|}{ Socioeconomic status of Tribal Patient } \\
\hline & & & Low & Medium & High \\
\hline CONS & $3(6.5 \%)$ & $2(6.0 \%)$ & $2(9.5 \%)$ & $0(00 \%)$ & $0(00 \%)$ \\
\hline Staphylococcus aureus & $12(26.0 \%)$ & $10(30.3 \%)$ & $6(28.5 \%)$ & $4(36.3 \%)$ & $0(00 \%)$ \\
\hline Streptocococcus pneumoniae & $3(6.5 \%)$ & $2(6.0 \%)$ & $0(00 \%)$ & $2(18.1 \%)$ & $0(00 \%)$ \\
\hline E. coli & $11(23.9 \%)$ & $8(24.2 \%)$ & $5(23.8 \%)$ & $3(27.2 \%)$ & $0(00 \%)$ \\
\hline Klebsiella pneumoniae & $5(10.8 \%)$ & $3(9.0 \%)$ & $2(9.5 \%)$ & $1(9.0 \%)$ & $0(00 \%)$ \\
\hline Pseudomonas aeruginosa & $2(4.3 \%)$ & $2(6.0 \%)$ & $1(4.7 \%)$ & $1(9.0 \%)$ & $0(00 \%)$ \\
\hline Acinetobacter baumannii & $1(2.1 \%)$ & $1(3.0 \%)$ & $0(00 \%)$ & $0(00 \%)$ & $1(100 \%)$ \\
\hline Candida albicans & $9(19.6 \%)$ & $5(15.1 \%)$ & $5(23.8 \%)$ & $0(00 \%)$ & $0(00 \%)$ \\
\hline
\end{tabular}

Table 4. Distribution of Organism according to the Sex \& Age of the Tribal patients

\begin{tabular}{|c|c|c|c|c|c|c|}
\hline \multirow[t]{2}{*}{ Type of Organism } & \multicolumn{2}{|c|}{ Sex of patients $(n=\%)$} & \multicolumn{4}{|c|}{ Age of Patients (years) $(n=\%)$} \\
\hline & $\begin{array}{l}\text { Female } \\
(20(60.6 \%)\end{array}$ & $\begin{array}{l}\text { Male } \\
(13(39.4 \%)\end{array}$ & $\begin{array}{l}<20 y r s \\
(6(18.1 \%)\end{array}$ & $\begin{array}{l}20-40 \text { yrs } \\
(15(45.4 \%)\end{array}$ & $\begin{array}{l}>40-60 \\
(7(21.2 \%)\end{array}$ & $\begin{array}{l}>60 \\
(5=15.1 \%)\end{array}$ \\
\hline CONS & $1(5)$ & $1(7.6)$ & $0(00)$ & $2(13.3)$ & $0(00)$ & $0(00)$ \\
\hline Staphylococcus aureus & $4(20)$ & $6(38.4)$ & $1(16.6)$ & $6(40)$ & $2(28.5)$ & $1(20)$ \\
\hline Streptocococcus pneumoniae & $2(20)$ & $0(00)$ & $0(00)$ & $1(6.6)$ & $1(14.2)$ & $0(00)$ \\
\hline E. coli & $6(30)$ & $2(15.3)$ & $3(50)$ & $1(6.6)$ & $3(42.8)$ & $1(20)$ \\
\hline Klebsiella pneumoniae & $1(5)$ & $2(15.3)$ & $0(00)$ & $1(6.6)$ & $0(00)$ & $2(40)$ \\
\hline Pseudomonas aeruginosa & $2(10)$ & $0(00)$ & $2(33.3)$ & $0(00)$ & $0(00)$ & $0(00)$ \\
\hline Acinetobacter baumannii & $0(00)$ & $1(7.6)$ & $0(00)$ & $0(00)$ & $1(14.2)$ & $0(00)$ \\
\hline Candida albicans & $3(15)$ & $2(15.3)$ & $0(00)$ & $4(26.6)$ & $0(00)$ & $1(20)$ \\
\hline
\end{tabular}

28(84.8\%) and Fungal 5(15.1\%).(Table 2)

In our study, CAUTI in Tribal patients was

affected by the Gram positive cocci $14(50 \%)$ and Gram negative bacilli 14 (50\%) in equal proportion and the remaining pathogens were the fungal Candida albicans 5(55.5\%). Over a period of one year, the Bacterial microbiological pattern of CAUTI in Tribal patients, were Staphylococcus aureus 10 $(30.3 \%)$ gram positive cocci followed by CONS 2(6.0\%) and Streptococcus Pneumoniae 2(6.0\%). Whereas in gram negative bacilli, E.coli 8 (24.2\%) were the most common pathogen followed by Klebsiella pneumoniae 3 (9.0\%), Pseudomonas aeruginosa 2 (6.0\%) and Acinetobacter baumannii $1(3.0 \%)$. Candida albicans was the only common fungal pathogen accounting in $5(55.5 \%)$ cases. The microbiological trend in the Low socioeconomic status group of Tribal patients were Staphylococcus aureus $6(28.5 \%)$, E.coli 5(23.8\%), Candida albicans 5(23.8\%), CONS 2 (9.5\%)and Klebsiella pneumoniae in 2 (9.5\%) cases, which was almost same in Medium socioeconomic status except Candida albicans and CONS which were totally not identified. The only organism detected in High socioeconomic status group was Acinetobacter baumannii 1 (100\%) in case.(Table 3 )

In this study, most affected patients in gender wise were Females, where $E$ coli 6 $(30 \%)$ the most common organism followed by Staphylococcus aureus 4(20\%), Candida albicans $3(15 \%)$ and in male Staphylococcus aureus 6 (38.4\%) followed by Klebsiella pneumoniae 2 (15.3\%) and Candida albicans 2(15.3\%) . Patients under 20 to 40 years of age, were most commonly affected by Staphylococcus aureus 6(40\%) and in 2 $(28.5 \%)$ cases in more than 40 to 60 years. Candida albicans 4 (26.6\%) was the second pathogen found predominantly only in age group 20 to 40 years but in case of more than 40 to 60 years of age group, it was E.coli 3(42.8\%). The pathogens recovered 
Table 5. Spectrum of Pathogens according to Duration of Catheterization \& Length of ICU stays.

\begin{tabular}{|c|c|c|c|c|c|}
\hline \multirow[t]{2}{*}{ Type of Organism } & \multicolumn{3}{|c|}{ Duration of Catheterisation (Days) } & \multicolumn{2}{|c|}{ Length of stays in the MICU (Days) } \\
\hline & $\begin{array}{l}<7 \\
(8=24.2 \%)\end{array}$ & $\begin{array}{l}7-14 \\
(22=66.6 \%)\end{array}$ & $\begin{array}{l}>14 \\
(3=9.0 \%)\end{array}$ & $\begin{array}{l}<14 \\
(14=42.4 \%)\end{array}$ & $\begin{array}{l}>14 \\
(19=57.5 \%)\end{array}$ \\
\hline CONS & $0(00 \%)$ & $2(9 \%)$ & $0(00 \%)$ & $2(14.2 \%)$ & $0(00 \%$ \\
\hline Staphylococcus aureus & $1(12.5 \%)$ & $9(40.9 \%)$ & $0(00 \%)$ & $5(35.7 \%)$ & $5(26.3 \%$ \\
\hline Streptocococcus pneumoniae & $2(25 \%)$ & $0(00 \%)$ & $0(00 \%)$ & $2(14.2 \%)$ & $0(00 \%$ \\
\hline E. coli & $1(12.5 \%)$ & $7(31.8 \%)$ & $0(00 \%)$ & $3(21.4 \%)$ & $5(26.3 \%$ \\
\hline Klebsiella pneumoniae & $1(12.5 \%)$ & $2(9 \%)$ & $0(00 \%)$ & $1(7.1 \%)$ & $2(10.5 \%$ \\
\hline Pseudomonas aeruginosa & $0(00 \%)$ & $0(00 \%)$ & $2(66.6 \%)$ & $0(00 \%)$ & $2(10.5 \%$ \\
\hline Acinetobacter baumannii & $0(00 \%)$ & $0(00 \%)$ & $1(33.3 \%)$ & $0(00 \%)$ & $1(5.2 \%$ \\
\hline Candida albicans & $3(37.5 \%)$ & $2(9 \%)$ & $0(00 \%)$ & $1(7.1 \%)$ & $4(21.0 \%$ \\
\hline
\end{tabular}

Table 6. Distribution of Pathogens according to associated co morbidities as risk factor in Tribal patient

\begin{tabular}{|c|c|c|c|c|c|c|}
\hline \multirow{2}{*}{\multicolumn{2}{|c|}{ Organism in CAUTI }} & \multicolumn{5}{|c|}{ Total Tribal Patients $(n=33)$} \\
\hline & & \multirow{2}{*}{\multicolumn{2}{|c|}{$\begin{array}{l}\text { Type-2DM Tribal } \\
\text { Patients }(n=4) \\
\text { Type of } \\
\text { Infection }\end{array}$}} & \multirow{2}{*}{\multicolumn{2}{|c|}{$\begin{array}{c}\text { SCD Tribal Patient } \\
(\mathrm{n}=13) \\
\text { Type of } \\
\text { Infection }\end{array}$}} & \multirow{3}{*}{$\begin{array}{l}\text { Other Tribal } \\
\text { Patients ( } n=16) \\
\text { Type of } \\
\text { Infection } \\
\text { (Single) }\end{array}$} \\
\hline \multirow{2}{*}{\multicolumn{2}{|c|}{ Types of Organism }} & & & & & \\
\hline & & $\begin{array}{l}\text { Single } \\
\text { infection(4) }\end{array}$ & $\begin{array}{l}\text { Mixed } \\
\text { infection(4) }\end{array}$ & $\begin{array}{l}\text { Single } \\
\text { infection(13) }\end{array}$ & $\begin{array}{l}\text { Mixed } \\
\text { infection(6) }\end{array}$ & \\
\hline \multirow[t]{7}{*}{ Bacterial } & CONS & $2(50 \%)$ & & $0(00 \%)$ & & $0(00 \%)$ \\
\hline & $\begin{array}{l}\text { Staphylococcus } \\
\text { aureus }\end{array}$ & $1(25 \%)$ & & $7(53.8 \%)$ & & $2(12.5 \%)$ \\
\hline & $\begin{array}{l}\text { Streptocococcus } \\
\text { pneumoniae }\end{array}$ & $0(00 \%)$ & $1(25 \%)$ & $2(15.3 \%)$ & & $0(00 \%)$ \\
\hline & E. coli & $1(25 \%)$ & & $2(15.3 \%)$ & $1(16.6 \%)$ & $5(31.2 \%)$ \\
\hline & $\begin{array}{l}\text { Klebsiella } \\
\text { pneumoniae }\end{array}$ & $0(00 \%)$ & $1(25 \%)$ & $1(7.6 \%)$ & $1(16.6 \%)$ & $2(12.5 \%)$ \\
\hline & $\begin{array}{l}\text { Pseudomonas } \\
\text { aeruginosa }\end{array}$ & $0(00 \%)$ & $1(25 \%)$ & $0(00 \%)$ & $1(16.6 \%)$ & $2(12.5 \%)$ \\
\hline & $\begin{array}{l}\text { Acinetobacter } \\
\text { baumannii }\end{array}$ & $0(00 \%)$ & & $0(00 \%)$ & & $1(6.2 \%)$ \\
\hline Fungal & Candida albicans & $0(00 \%)$ & $1(25 \%)$ & $1(7.6 \%)$ & $3(50 \%)$ & $4(25 \%)$ \\
\hline
\end{tabular}

in the age group below 20years was E. coli 3 (50\%) predominantly. In our study, a significant association was found of Klebsiella pneumoniae $2(40 \%)$ with the age group above 60 years.(Table 4)

According to the duration of catheterization in our study,more isolates were identified between 7 to 14 days. These isolates were Staphylococcus aureus 9 (40.9\%), E.coli $7(31.8 \%)$, Candida albicans 2(9.0\%). But in less than 7 days, the isolates were Candida albicans 3 (37.5\%) predominantly followed by Streptococcus pneumoniae 2 (25\%). Pseudomonas aeruginosa
$2(66.6 \%)$ was the most common isolate with Acinetobacter baumannii in 1 (33.3\%) case, were found in catheterization more than 14 days. Among the 33 tribal patient with CAUTI, 14 (42.4\%) were stayed for a duration of less than 14 days, where the isolates were Staphylococcus aureus 5(35.7\%), E.coli 3(21.4\%), Streptocococcus pneumoniae 2 (14.2\%). In case of,length of stay for more than 14 days, the potential isolates identified were E.coli and Staphylococcus aureus, in equal proportion in $5(26.3 \%)$ cases followed by Candida albicans 4 (21.0\%), (Table 5) In our study, we not only identified single 
but also mixed infections due to more than one organism in tribal patients associated with Type2 Diabetes mellitus and Sickle cell anemia in our MICU. CONS 2 (50\%) was the most common single infection found in Tribal patient with Diabetes mellitus, Where as in patients with Sickle cell anemia, Staphylococcus aureus 7 (53.8 \%) was the most common pathogen as single infection preceding Streptocococcus pneumoniae and E.coli, each in 2 (15.3\%) cases. (Table 6)

\section{DISCUSSION}

Urinary tract infections (UTIs) are the most common type of healthcare-associated infection reported to the National Healthcare Safety Network (NHSN). Among UTIs acquired in the hospital, approximately $75 \%$ are associated with a urinary catheter. The Incidence of CAUTI in our study was $24.2 \%$, which was less than the findings of $29.55 \%$ in one study by Sawsan et al. ${ }^{10}$. In their study they considered patients from both Ward and ICU, so their incidence was high because of large sample size as compared to our study in MICU only.

The case fatality in CAUTI is three times higher in patient with bacteremia than non bacteremic patients ${ }^{11}$. According to the 2006 to 2007 statistics from the NHSN, the most frequent pathogens associated with CAUTI were E. coli (21.4\%), Candida spp. (21.0\%), Enterococcus spp. (14.9\%), P. aeruginosa (10.0\%), K. pneumoniae $(7.7 \%)$, and Enterobacter spp. $(4.1 \%)^{12}$. This microbiological trend was different in our study, where Staphylococcus aureus 12 (26.0\%)was first followed by E. coli 11 (23.9\%), Candida albicans 9 (19.5\%), Klebsiella pneumoniae 5 (10.8\%), CONS 3 (6.5\%), Streptococcus pneumoniae 3 (6.0\%), Pseudomonas aeruginosa 2 (4.3\%) and Acinetobacter baumannii 1 (2.1\%) in order of frequency. We did not identified any Enterococcus spp or Enterobacter spp in our study. Acinetobacter baumannii, a gram negative isolate was recovered in our study, which was not in NHSN statistics list. One study conducted in India by S Pramodhini et al. $^{13}$ where they found $70 \%$ of isolates were E. coli. Where as, in our study,Staphylococcus aureus was more common than E coli, may be due to association of co morbidities DM, SCA in Tribal patient.

The potential significant risk factors other than urinary catheterization are gender, age, uncontrolled diabetes and long hospital stay ${ }^{14,15}$. D. M. Livermore et al. ${ }^{16}$ conducted a study over antibiotic resistance of pathogen in different location,where they found that prevalence of pathogens and their features may vary with time and geographical area. In our study, the common causative organism in group were Gram positive cocci 14 (50\%) and Gram negative bacilli 14 (50\%) in equal proportion and the remaining were 5 (55.5\%) fungal in patient of tribal area.

In one study by Muhammad D.H. et al. ${ }^{17}$ where they found that female gender is a common risk factor for CAUTI in Intensive care units $^{17}$. This is similar to our study. E coli 6 (30\%) was the most common organism in female Tribal patients followed by Staphylococcus aureus 4 (20\%), Candida albicans 3 (15\%) and Pseudomonas aeruginosa $2(10 \%)$, which was near to the findings observed in their major female group, in the year 2018 studied by Govinda Maharajan et al as Escherichia coli 56.9\% (37/65) followed by Klebsiella pneumoniae 10 (15\%). In Both the study, E. coli was the common pathogen isolated in CAUTI in the ICU.

Muhammad D H et al. ${ }^{17}$ also observed in their study that, CAUTI caused by $E$. coli, was higher in patients of reproductive age (21-30 years) group, irrespective of catheterization and a higher percentage of $P$. aeruginosa was also found in catheterized patients of the same age group. But in our study, it was observed in tribal patients below 20 years of age, may be due to a lack of sufficient knowledge of hygiene practices. Similar trend was observed for $E$. coli in tribal patients of age group above40 to 60 years, where as Klebsiella pneumoniae was recovered in patients of age group above 60 years. In both the groups, the variation in pathogens, may be due to the association of co morbidity Diabetes mellitus. The highest proportion of Staphylococcus aureus was found in the age group 20 to 40 years followed by Candida albicans. This observational finding may be due to association of SCA and sexually active reproductive age.

Education, income, marital status, are all components of socioeconomic status and connected to overall health and well-being. Lower income was significantly associated with higher risk of developing moderate/severe Lower Urinary 
Tract infection. This was reflected in our study as Low socioeconomic status group 21 (63.6\%) were most affected than medium 11 (33.3\%) and high group, where the isolates in frequency were, Staphylococcus aureus 6 (28.5\%), E.coli 5 (23.8\%), Candida albicans 5 (23.8\%), CONS 2 (9.5\%) and Klebsiella pneumoniae 2 (9.5\%). We were expected, E. coli and Candida as the major pathogen in low socio economic group because of unawareness of hygiene practices and life style but came after Staphylococcus aureus in order of frequency and in equal proportion. The only organism detected in High socioeconomic status group was Acinetobacter baumannii in 1 (100\%) case.

Duration of Catheterization is an important risk factor for CAUTI because, the duration of time should be sufficient for the biofilm of the pathogen to form on the surface of the catheter and the drainage system to developed $\mathrm{CAUTI}^{18}$. In our study, the risk of CAUTI was three times more, in patients used catheter 7 to 14 days, than less than 7 days. This finding is similar to a study conducted by Anggreiny Anggi et al. ${ }^{19}$. Candida albicans was the most frequent pathogen detected in Tribal patients with less than 7 days of duration of catheterization.The most higher risk group using catheter 7 to 14 days were associated with common pathogen Staphylococcus aureus followed by E.coli, that may be due to the infection prone Sickle cell anemic young Tribal patients.

Length of ICU stay is associated with increased risk of CAUTI because in the presence of catheter for long time will inoculate organisms into the bladder and promote colonization by providing a surface for bacterial adhesions and causing mucosal irritation leading to CAUTI. Talaat $M$ et al. ${ }^{20}$ found in their study that prolonged hospital stay had significant higher risk to develop CAUTI. The Tribal patients Who stayed in MICU for less than 14 days were more commonly affected with Staphylococcus aureus 5 (35.7\%) followed by E.coli 3 (21.4\%), CONS 2 (14.2\%). But CAUTI was more in Patients staying for more than 14 Days in MICU, where the pathogen were E.coli 5 (26.3\%) and Staphylococcus aureus 5 (26.3\%) in equally proportionately detected followed by Candida albicans.

Platt et al. ${ }^{21}$ in their study, documented, presence of diabetes as a risk factor for CAUTI due to two possibilities : an increased prevalence of perineal colonization by potential pathogens and an increased ability of the urine of some patients with diabetes to support microbial growth ${ }^{20}$. In our study, CONS 2 (50\%) was the pathogen responsible for, CAUTI in Tribal patient with Diabetes mellitus and Staphylococcus aureus 7 (53.8\%)was the pathogen in Tribal patient with Sickle cell anemia followed by Streptocococcus pneumoniae 2 (15.3\%) and E.coli 2 (15.3\%). The pathogens detected in Tribal patients without any risk factors were E. coli 5 (31.2\%) followed by Candida albicans in $4(25 \%)$ cases.

\section{CONCLUSION}

From the present study, We reached in a conclusion that, mainly three common pathogens Staphylococcus aureus, E.coli and Candida albicans were identified in Tribal patients with CAUTI, depending on the factors influencing them. Our analysis precisely of this population, brings several important and unique findings, which will aid in the development of some new or update guidelines for the prevention of CAUTI in the ICU. With the knowledge of antibiotic resistance pattern of these pathogens, new antibiotic policy will be developed to reduce empirically use of antibiotics, their by reduce length of ICU stay, morbidity and mortality in these Tribal patients in the ICU of Tribal tertiary care centre.

\section{Recommendation}

More surveillance study on CAUTI over these Tribal patients with large sample size over a long time period was recommended to reach a solid guideline with antibiotic policy in MICU of Tribal tertiary care centre.

\section{ACKNOWLEDGMENTS}

None.

\section{CONFLICT OF INTEREST}

All authors declares that there is no conflict of interest.

\section{AUTHORS' CONTRIBUTION}

All authors listed have made a substantial, direct and intellectual contribution to the work, and approved it for publication.

\section{FUNDING}


None.

\section{DATA AVAILABILITY}

All datas generated or analyzed during this study are included in the manuscript.

\section{ETHICS STATEMENT}

Data from patients obtained after proper consent.

\section{REFERENCES}

1. Sukandar E, Dewasa ISKP. Risk factor for Catheter associated urinary Tract Infection, Buku Ajar IImu Penyakit Dalam Jilid I. Balai Penerbit FKUI, Jakarta, 2006; 10:564-568.

2. Eriksen HM, Iversen BG, Aavitsland P. Prevalence of nosocomial infections in hospitals in Norway, 2002 and 2003. J Hosp Infect. 2005;60:40-45. doi: 10.1016/j. jhin.2004.09.038

3. Lizioli A, Privitera G, Alliata E, et al. Prevalence of nosocomial infections in Italy: result from the Lombardy survey in 2000. J Hosp Infect. 2003;54:141148. doi: 10.1016/S0195-6701(03)00078-1

4. Stamm WE. Catheter-associated urinary tract infections: Epidemiology, Pathogenesis and prevention. Am J Med. 1991;91(3B):65S-71S. doi: 10.1016/00029343(91)90345-X

5. Khan Y, Venkateshwarlu C, Sreenivas G, Rahul G. Study of incidence and risk factors of UTI in catheterized patients admitted at tertiary care hospital. Nizamabad,Telangana,India. International Archives of Integrated Medicine. 2016;3(8):83-92.

6. Chenoweth C, Saint S. Preventing Catheter-Associated Urinary Tract Infections in the Intensive Care Unit. Crit Care Clin. 2013;29:19-32. doi: 10.1016/j. ccc.2012.10.005

7. Nicolle LE. Catheter-associated urinary tract infections. Antimicrobial Resistance and Infection Control. 2014;3:23. doi: 10.1186/2047-2994-3-23

8. Lo E, Nicolle LE, Coffin SE, et al. Strategies to prevent catheter-associated urinary tract infections in acute care hospitals: 2014 update. Infection Control \& Hospital Epidemiology. 2014;35(5):464-479. doi: 10.1086/675718

9. Agodi A, Barchitta M. Epidemiology and Control of Urinary Tract Infections in Intensive Care Patients. In: Nikibakhsh, A. (Ed.) Clinical Management of Complicated Urinary Tract Infection. InTech. 2011. doi: 10.5772/23113

10. Omer SA, Zahran FE, Ibrahim A, et al. Risk Factors for Catheter Associated Urinary Tract Infections (CAUTI) in Medical Wards and Intensive Care Units (ICU). Journal of Microbiology Research 2020;10(1):1-5. doi:10.5923/j.microbiology.20201001.01

11. Ahmed MMI, Ahmed T, Ahmed S, Khan AR. Microbiology of urinary Tract infection. Microbial Agents \& Predisposing Factors, Chapter 3: 24. doi: 10.5772/ intechopen/80080

12. Edwards JR, Peterson KD, Andrus ML, et al. National Healthcare Safety Network (NHSN) report: data summary for 2006 issued on 2007. Am Jinfect Control.2007;35(5):290-301. doi: 10.1016/j. ajic.2007.04.001

13. Pramodhini S, Niveditha S, Umadevi S, Kumar S, Stephen S. The Isolation and the Biofilm Formation of Uropathogens in the Patients with Catheter Associated Urinary Tract Infections (UTIs). J Clin Diagn Res. 2012;6(9):1478-82. doi: 10.7860/ JCDR/2012/4367.2537

14. Narayanan A, Nair MS, Muyyarikkandy MS,Amalardjou MA. Inhibition and Inactivation of Uropathogenic Escherichia coli Biofilms on Urinary Catheters by Sodium Selenite. Int J Mol Sci. 2018;19(6):1703. doi: 10.3390/ijms19061703

15. Muramatsu K, Fujino Y, Kubo T, Otani M, Fushimi K, Matsuda S. Efficacy of Antimicrobial Catheters for Prevention of Catheter-Associated Urinary Tract Infection in Acute Cerebral Infarction. J Epidemiol. 2018;28(1):54-58. doi: 10.2188/jea.JE20170022

16. Livermore DM, Pearson A. Antibiotic resistance: location, location, location. Clin Microbiol Infect. 2007;13(supplement 2):7-16. doi: 10.1111/j.14690691.2007.01724.x

17. Hossain MD, Ahsan S, Kabir MS. Antibiotic resistance patterns of uropathogens isolated from catheterized and noncatheterized patients in Dhaka, Bangladesh. Tzu Chi Medical Journal. 2014:26(3):127-131. doi: 10.1016/j.tcmj.2014.06.003

18. Gould CV, Umscheid CA, Agarwal RK. Guideline for Prevention of Catheter-Associated Urinary Tract Infections. 2009.

19. Anggi A, Wijaya DW, Ramayani OR. Risk Factors for Catheter-Associated Urinary Tract Infection and Uropathogen Bacterial Profile in the Intensive Care Unit in Hospitals in Medan, Indonesia. Open Access Maced J Med Sci. 2019;7(20):3488-3492. doi: 10.3889/ oamjms.2019.684

20. Talaat M, Hafez S, Saied T, Elfeky R, El-Shoubary W, Pimentel G. Surveillance of catheter-associated urinary tract infection in 4 intensive care units at Alexandria university hospitals in Egypt. Am J Infect Control. 2010;38(3):222-228. doi: 10.1016/j.ajic.2009.06.011

21. Platt R, Polk BF, Murdock B, Rosner B. Risk factors for nosocomial urinary tract infection. Am J Epidemiol. 1986;124:977-985. doi: 10.1093/oxfordjournals.aje. a114487 